\title{
Perceived Motivators and Constraints among Regular Players of Pick-Up Basketball Games 經常參加籃球運動群體的動機與障礙
}

\author{
Jianyu WANG \\ Department of Physical Education and Kinesiology, \\ California State University, Bakersfield, USA
}

\section{Wei BIAN}

Physical Education Department,

Slippery Rock University, USA

\section{王建宇}

美國加州州立大學貝克斯菲爾德分校體育系

\section{市薇}

美國滑石大學體育系
Wenhao LIU

Physical Education Department,

Slippery Rock University, USA

\author{
Jiangong TAN \\ School of Health, Physical Education, \& \\ Leisure Services, \\ University of Northern Iowa, USA
}

\section{劉文浩}

美國滑石大學體育系

譚建共

美國北依阿華大學健康體育休閒系

\begin{abstract}
The purpose of this study was to examine perceived motivators and constraints among regular players of pick-up basketball games. Sixty-five basketball players were invited to participate in the study. The instrument assessing participants' perceived motivators and constraints of participating in pick-up basketball games was adapted from the works on leisure motivators and constraints. Results indicated that the primary motivators for the players playing pick-up basketball games were having fun (77.9\%), improving physical fitness (55.9\%), becoming fit (52.9\%), and improving basketball skills (41.2\%). The major constraints the players perceived were lack of leisure time (55.9\%), lack of basketball courts (45.6\%), hard to find friends to play with (17.6\%), and too much work (16.2\%). The findings of the study may imply that in order to promote physical activity policy-makers should help create better physical environments such as the access to the basketball courts. Additionally, physical education professionals must help young people develop motor skills to enjoy the activity.
\end{abstract}

\section{摘 要}

本文旨在揭示經常參加籃球運動群體的動機與障礙。六十五位經常參加籃球運動的人士應邀參加本研究。結果顯示經常 參加籃球運動主要的動機包括有興趣 $(77 \circ 9 \%)$ 、提高體能 $(55 \circ 9 \%)$ 、改進健康 $(52 \circ 1 \%)$ 、提高籃球技術 $(41 \circ 2 \%)$ 。主 要障礙包括缺少休閒時間 $(55 \circ 9 \%)$ 、缺乏場地 $(45 \circ 6 \%)$, 難以找到朋友一起參與 $(17 \circ 6 \%)$ 、太多工作 $(16 \circ 2 \%)$ 。本研 究結果表明為了更好促進大眾體育鍛煉，決策者須考慮改善體育鍛煉的環境，同時體育專業人士應幫助青少年發展運動技能。 


\section{Introduction}

Physical inactivity has been identified as a major public health problem in the United States (U. S. Department of Health and Human Services [USDHHS], 1996) and a key contributor to an unprecedented epidemic of childhood obesity (USDHHS, 2000). Despite documented health benefits of physical activity, the majority of Americans do not achieve the recommended amount of physical activity (USDHHS, 1996). Thus, it is critical to understand why people choose participating (or not participating) in physical activity.

Researchers have examined motivators that lead to individuals participating in physical activity and suggested that the major motivator for adults to participate in physical activity is health benefits (Cohen-Mansfield, Marx, \& Gurlnik, 2003; Dishman, 1994; Hildebrand \& Johnson, 2001). In their study, Cohen-Mansfield and colleagues (2003) found that primary motivators for senior citizens to exercise were feeling better and improving health. Another study showed that the most important reasons for college students to take physical activity classes were enjoying the activity and improving fitness (Hildebrand \& Johnson, 2001). Furthermore, Dishman's (1994) study found that a doctor's advice, peer support, and access to exercise facilities often affected the elders' attitudes to engage in physical activities.

As for school students, several factors were identified to contribute to their physical activity participation. It was reported that school students chose participating in sports because of fun, social benefits, fitness, and competition (Sirard, Pfeiffer, \& Russell, 2006). This finding is consistent with the results of a recent study that indicated students valued health, enjoyment, and social interaction in physical activity participation (Liu, Wang, \& Xu, 2008). In addition, sports skill levels were reported as a factor as well as contributing to school students' physical activity participation (Liu \& Chepyator-Thomson, 2008).

Researchers have also tried to understand the barriers or constraints of participating in physical activity and sports among different populations such as adolescents (Sirard, Pfeiffer, \& Russell, 2006), college students (Daskapan, Tuzun, \& Eker, 2006), women in the rural area (Osuji, Lovegreen, Elliott, \& Brownson, 2006), and the elderly (e.g., Alexandris, Tsorbatzoudis, \& Grouios, 2001; CohenMansfield, Marx, \& Gurlnik, 2003; Alexandris, Barkoukis,
Tsorbatzoudis, \& Grouios, 2003; Rashinaho, Hirvensalo, Leininen, Litunen, \& Rantanen, 2007). For example, Osuji et al. (2006) reported that the women in the rural area identified such major barriers to physical activity as no time (61.1\%), bad weather (59.4\%), no motivation (57.1\%), not safe (42.8\%), and no companion to exercise with $(33.0 \%)$. In their study, Cohen-Mansfield et al. (2003) found that the primary barriers to exercise as perceived by the elderly people were health problems/pains (53.4\%), lazy/not motivated (29.3\%), no time/too busy (25.0\%) and fatigue $(11.6 \%)$.

Recently, researchers have used the theory of leisure constraints to examine physical activity participation (e.g., Alexandris, Barkoukis, Tsorbatzoudis, \& Grouios, 2003). The theory has widely been used to explain why people choose participating in leisure and recreational activities. According to Crawford and Godbey (1987), leisure constraints are classified into intrapersonal, interpersonal, and structural constraints. Intrapersonal constraints are internal ones related to individual psychological states and attributes. Interpersonal constraints refer to those associated with interaction with other people such as family members, friends, and neighbors. Structural constrains are external ones including such factors as the lack of opportunity and facilities. In their study, Alexandris et al. (2003) reported that the major constraints for the elderly to engage in physical activity were accessibility to facilities (structural constraints), individual /psychological factors (intrapersonal constraints), financial reasons (structural constraints), and lack of partners (interpersonal constraints).

While previous studies on motivators and constraints of physical activity and sports have targeted several subgroups of population (such as adolescents, college students, the elderly, and women in rural areas), it is desirable to address regular participants of physical activity in order to better understand motivations and constraints of regular physical activity participation. In fact, physical education scholars have urged investigation into regular physical activity participants (e.g., Rink, 2005), and the study in this direction could help better understand why people choose participating in and maintaining physical activity. Therefore, the purpose of this study was to examine perceived motivators and constraints among regular players of pick-up basketball games. 


\section{Method}

\section{Participants}

One hundred and twelve adults (18 years old or older) who were playing pick-up basketball games in the public facilities in three different cities in central California were initially invited to participate in a survey. A pick-up basketball game is a basketball game that individuals meet at the courts during their leisure time and select partners to play basketball games for fun and the players may play 5 on 5 or 4 on 4 games or any other formats of the games they like. Of these 112 players, 65 (62 men and 3 women) were, by survey, identified as regular players who played pick-up basketball games at least once per week and had a cumulative time of 40 minutes or more each week for a minimum of one year. These 65 players were the final participants in this study and their ages ranged from 18 to 64 years, and the average age for the sample was 33.1 years (SD = 12.2). The participants included African Americans (34.6\%), Caucasians (33.3\%), Hispanic Americans (21.7\%), Asians $(7.7 \%)$ and other races (2.6\%). Approximately $50 \%$ of the participants had played in pick-up games for ten years or more.

\section{Instrumentation}

The instrument assessing participants' perceived motivators and constraints of participation in pick-up basketball games was adapted from the works on leisure motivators (Manfredo, Driver, \& Tarrant, 1995) and leisure constraints (Jackson \& Rucks, 1995). The questionnaire included the question "What are the major purposes for you to play basketball games during leisure time?" for the motivators with eight different answers; and the question "What factors may prevent you from playing basketball games during leisure time?" for the constraints with nine different answers. The questionnaire also included the question "What factors may affect your decision to play basketball games during leisure time?" with eight different answers. For each question, participants could select more than one answer whenever appropriate. In addition, the instrument had a section for the participants to report their demographic information.

\section{Data Collection and Analysis}

All participants signed the consent forms and then completed the survey on the basketball courts at the public facilities. The first author or his research assistants administered the surveys. It took about 15 minutes for the participants to fill in the questionnaire. Descriptive statistics were used in the study and percentages on perceived motivators and constraints to play pick-up basketball games were computed.

\section{Results}

This section will report descriptive statistics of motivators, constraints, and factors affecting decisions to play pick-up basketball games among the regular participants. As presented at Table 1, results indicated that the primary motivators for the players to play pickup basketball games were having fun (77.9\%), improving physical fitness (55.9\%), becoming fit (52.9\%), improving basketball skills (41.2\%), reducing tension and stress (39.7\%), meeting and making friends (32.1\%), and seeking stimulation $(11.5 \%)$.

The major constraints the players perceived were lack of leisure time (55.9\%), lack of basketball courts (45.6\%), hard to find friends to play with (17.6\%), too much work (16.2\%), high entry fee of basketball court (14.1\%), safety concern $(11.5 \%)$, and lack of transportation $(9.0 \%)$ (See Table 2). Data in Table 3 indicate that important factors that might affect the decision to play the games were available time in the day (61.8\%), location of basketball court (61.8\%), other players' skill levels (33.8\%), friend accompanying (29.4\%), entry fee of basketball court (26.9\%), environment safety (19.2\%), and the participant's own skill levels (11.5\%). 
Table 1. Percentage of Perceived Motivators to Play Pick-up Basketball Games.

\begin{tabular}{lc}
\hline Motivators & Percentage \\
\hline Having fun & 77.9 \\
Improving physical fitness & 55.9 \\
Becoming fit & 52.9 \\
Improving basketball skills & 41.2 \\
Reducing tension and stress & 39.7 \\
Meeting and making friends & 32.1 \\
Seeking stimulation & 11.5 \\
Other & 5.1 \\
\hline
\end{tabular}

Table 2. Percentage of Perceived Constraints to Play Pick-up Basketball Games.

\begin{tabular}{lc}
\hline Constraints & Percentage \\
\hline Lack of time & 55.9 \\
Lack of basketball courts & 45.6 \\
Hard to find friends to play with & 17.6 \\
Too much work & 16.2 \\
High entry fee & 14.1 \\
Not safe & 11.5 \\
Lack of transportation & 9.0 \\
Lack of basketball skill & 2.6 \\
Other & 5.1 \\
\hline
\end{tabular}

Table 3. Percentage of Perceived Factors Affecting Participation to Play Pick-up Basketball Games.

\begin{tabular}{lc}
\hline Factors & Percentage \\
\hline Location of basketball court & 61.8 \\
Available time in the day & 61.8 \\
Other players' skill levels & 33.8 \\
Friends accompanying & 29.4 \\
Entry fee of basketball court & 26.9 \\
Environment safety & 19.2 \\
Own skill levels & 11.5 \\
Other & 10.3
\end{tabular}




\section{Discussion and Conclusions}

This study examined perceived motivators, constraints, and factors affecting the decision to play pick-up basketball games among regular participants. Previous studies have revealed that the major motivators for the elderly and young people participating in physical activity are slightly different. While the elderly who choose participating in physical activity emphasize health benefits (Cohen-Mansfield, Marx, \& Gurlnik, 2003; Dishman, 1994), the youth and young adults stress both having fun and improving fitness (Hildebrand \& Johnson, 2001; Sirard, Pfeiffer, \& Russell, 2006). Results of the present study indicate that regular players' top motivators for participating in pick-up basketball games are for fun and health benefits, which are consistent with major motivators found in previous studies addressing other subgroups of population. Enjoyment and health benefits are reported by college students (Hidebrand \& Johnson, 2001) and public school students (Liu et al., 2008; Sirard et al., 2006) as major reasons for physical activity participation. Obviously, playing pick-up basketball games provide individuals with the opportunity for adults to have fun and improve their health as well.

The current study also suggested that psychological and social benefits (reducing tension and stress, meeting and making friends, and seeking stimulation) are also important motivators for the participants to regularly participate in pick-up basketball games. Due to the nature of "play", competition, and involving a group of people in basketball games, apparently it might be easier to obtain these benefits by playing pick-up basketball games than performing individual physical activities such as walking and jogging. This also helps explain why nearly half of the participants in the study have played pick-up basketball games for more than ten years. The participants playing pick-up basketball games for such a long time may bear strong motivators that include not only fun and health benefits, but also psychological and social benefits, such as reducing tension and stress, meeting and making friends, and seeking stimulation.

Finally, improving basketball skills is reported as a motivator by $41.2 \%$ of the participants. The finding could be interpreted that participating in pick-up basketball games needs a competent level of basketball skills. This explanation is consistent with previous studies. Sport skill levels were reported as a factor contributing to school students' physical activity participation, and athletically skilled students were more inclined to participate in physical activity (Portman, 1995). It was also reported that sports levels were positively related to school children's interests in participation in physical activity (Liu \& Chepyator-Thomson, 2008). It could be easy to understand that fun, health benefits, and psychological and social benefits would be compromised without a competent level of basketball skills when participating in pick-up basketball games.

In addition to motivators, regular players of pickup basketball games have experienced constraints in each of the three categories based on the theory of leisure constraint by Crawford and Godbey (1987). Specifically, constraints identified by the players are intrapersonal ones (lack of leisure time, too much work, and lack of basketball skill), interpersonal ones (hard to find friends to play with, no friends to accompany), and structural ones (lack of basketball courts, high entry fee to basketball courts, safety concern, and lack of transportation).

It is noticed that regular players of pick-up basketball games indicate limited intrapersonal constraints compared with some subgroups of population. For example, intrapersonal constraints including fatigue, no time, no energy, no motivation, and no interest in exercise are major barriers to physical activity for women in rural areas (Osuji et al., 2006). As for the elderly, intrapersonal constraints including health problems/ pains, lazy/not motivated, no time, and fatigue constitute a primary constraint as well (Cohen-Mansfield et al., 2003). However, intrapersonal constraints reported by regular players of pick-up basketball games include time constraint, and with no constraint of motivation or fatigue at all.

Compared with intrapersonal constraints, interpersonal and structural constraints might become more critical factors in determining regular players' participation in basketball games. The data on factors affecting participation in pick-up basketball games has suggested that six of the factors are with interpersonal or structural constraints (location of basketball court, available time of the day, other players' skill levels, friends accompanying, entry fee of basketball courts, and environment safety). Playing pick-up basketball games demands more people involved than participating in individual sports, requires all players available at the same time and to have an 
appropriate level in basketball skills, and needs necessary facilities. Therefore, interpersonal and structural constraints might be more obvious in playing basketball games than participating in individual physical activity.

In summary, the present study examined perceived motivators, constraints, and factors affecting the decision to play pick-up basketball games among regular participants. Top motivators for participating in pickup basketball games are for fun and health benefits, followed by psychological and social benefits (reducing tension and stress, meeting and making friends, and seeking stimulation). In addition, improving basketball skill is another motivator to play pick-up basketball games. With regard to constraints, interpersonal (no friends to accompany) and structural (lack of basketball courts, high entry fee to basketball courts, safety concern, and lack of transportation) constraints are more serious than intrapersonal ones (lack of leisure time, etc.) for regular participants. Finally, of the seven identified factors affecting participation in pick-up basketball games, six of them are again related to interpersonal (friends accompanying, other players' skill levels, etc.) or structural constraints (location of basketball courts, entry fee, etc.)

While other relevant studies address people's physical activity participation in general, this study is unique in addressing regular participants in a specific recreational sport (pick-up basketball game). The study helps understand important factors for people to maintain a specific physical activity, and some implications can be expected. For example, physical education teachers may want to help students master basketball skills at an application level if they are expected to use basketball as a lifelong tool for exercise. Also, decision makers in administration may need to consider how to make basketball courts more accessible and available for the regular basketball players.

The study, however, bears some limitations. Investigation into a single recreational sport limits participants, and the sample is sex-biased with few females. More similar research with larger samples and more balanced sex distribution is needed in the future.

\section{Reference}

Alexandris, K., Barkoukis, V., Tsorbatzoudis, H., \& Grouios, G. (2003). A study of perceived constraints on a community -based physical activity program for the elderly in Greece. Journal of Aging and Physical Activity, 11(3), 305-318.

Alexandris, K., Tsorbatzoudis, C., \& Grouios, G. (2001). Perceived constraints on recreational sport participation: Investigating their relationship with intrinsic motivation, extrinsic motivation and amotivation. Journal of Leisure Research, 34(3), 233252.

Cohen-Mansfield, J., Marx, M. S., \& Gurlnik, J. M. (2003). Motivators and barriers to exercise in an older community dwelling population. Journal of Aging and Physical Activity, 11(2), 242-253.

Crawford, D., \& Godbey, G. (1987). Reconceptualizing barriers to family leisure. Leisure Science, 9, 119127.

Daskapan, A, Tuzun, E. H., \& Eker, L. (2006). Perceived barriers to physical activity in university students. Journal of Sports Science \& Medicine, 5(4), 615-620.

Dishman, R. K. (1994). Motivating older adults to exercise. Southern Medicinal Journal, 87(5),S79-S82.

Hildebrand, K. M., \& Johnson, D. J. (2001). Determinants of college physical activity class enrollment: Implications for high school physical education. The Physical Educator, 58, 51-56.

Jackson, E. L., \& Rucks, V. C. (1995). Negotiation of leisure constraints by junior-high and high-school students: An exploratory study. Journal of Leisure Research, 27, 85-105.

Liu, W., \& Chepyator-Thomson, J. R. (2008). Associations among field dependence-independence, sports participation, and physical activity level among school children. Journal of Sports Behavior, 31, 130-146. 
Liu, W., Wang, J., \& Xu, F. (2008). Middle school children's attitudes toward physical activity. The ICHPER·SD Journal of Research, 3(2), 78-85.

Manfredo, M.., Driver, B. L., \& Tarrant, M. A (1995). Leisure motivation: A met-Analysis of the recreation experience performance scale. Journal of Leisure Research, 28, 188-213.

Osuji, T., Lovegreen, S., Elliott, M., \& Brownson, R. (2006). Barriers to physical activity among women in the rural Midwest. Women \& Health, 44 (1), 41-55.

Rashinaho, M., Hirvensalo, M, Leininen, R, Litunen, T.,\& Rantanen, T. (2007). Motives for and barriers to physical activity among older adults with mobility limitations. Journal of Aging and Physical Activity, 15(1), 90-102.

Rink, J. E. (2005). How young adults enjoy and sustain physical activity: Introduction. Journal of Physical Education, Recreation, and Dance, 76(8), 18-18.

Sirard, J. R., Pfeiffer, K. A., \& Russell, R. (2006). Motivational factors associated with sports program participation in middle school students. Journal of Adolescent Health, 38(6), 696-703.
U.S. Department of Health and Human Services. (1996). Physical activity and health: A report of the Surgeon General. Atlanta, GA: Centers for Disease Control and Prevention.

U.S. Department of Health and Human Services. (2000). Promoting better health for young people through physical activity and sports: A report to the president from the secretary of Health and Human Service and the secretary of Education. Atlanta, GA: Centers for Disease Control and Prevention. Retrieved Sept. 7, 2005, from http://www.cdc.gov/nccdphp/dash/ presphysactrpt/index.htm

\section{Correspondence:}

Jianyu Wang, Ph.D.

Associate Professor

Department of Physical Education and Kinesiology

California State University, Bakersfield

9001 Stockdale Highway

Bakersfield, CA 93311-1022

Email: jwang4@csub.edu 